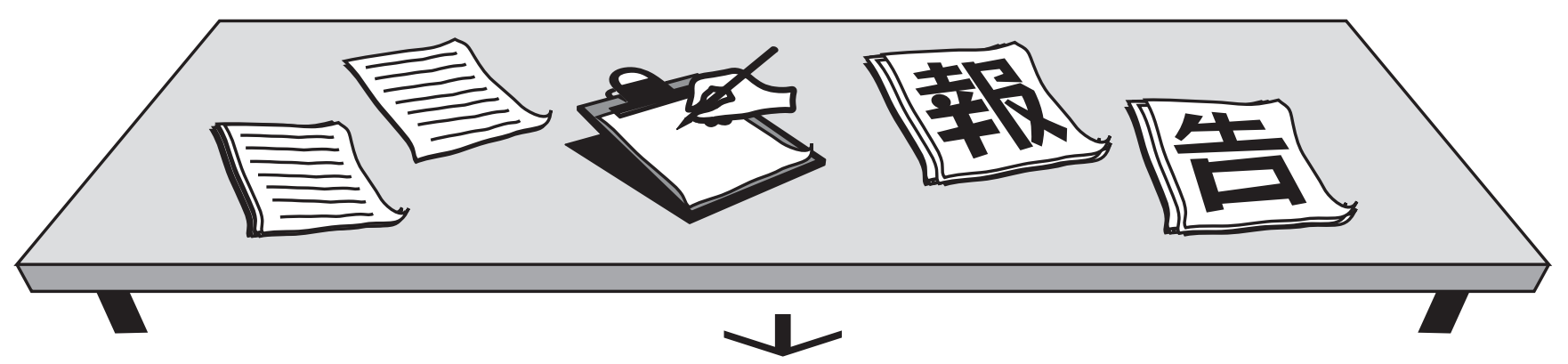

\title{
2016年映像情報メディア学会年次大会
}

\section{(正会員) 内 藤 整}

\section{1.まえがき}

2016年映像情報メディア学会年次大会は, 8 月 31 日 (水) 〜9月 2 日 (金)の 3 日間, 三重大学にて開催された。一般 講演 33 部門 144 件, 公開講演会 1 件, シンポジウム講演 4 セッション 18 件, チュートリアル講演 1 セッション 4 件, SET 特別講演 1 件, KIBME招待講演 1 件, および企業によ るデモ展示 3 件を含めた内容で構成され, 登録参加者数は 348 名と, ここ数年の大会とほぼ同程度の参加者人数で あったが， 3 日間の延べ参加人数は 1,197 名と過去 9 年の中 では最多人数を記録した.

\section{2. 年次大会の構成}

大会 3 日間を通して, 三重大学工学部講義棟にある会場 で発表が行われた。また今回の年次大会では，ブラジル SET との共同企画として, 同時期にサンパウロで開催され ていたSET Expoとのジョイントセッションを実施するこ とができ, 今後の両学会の関係強化に向け貴重な一歩を踏 み出すことができた. 大会 2 日目の講演終了後に, 懇親会 会場にて表彰式が執り行われた. 昨年の年次大会および冬 季大会から選奨規定に沿って選出された若手研究者 5 名に 対し, 鈴木記念奨励賞の表彰が, 続いて, 昨年の冬季大会 で優秀な発表を行った学生 5 名に対し, 学生優秀発表賞の 表彰がいずれも高畑会長より行われた。 また, 論文査読功 労賞の表彰も, 年次大会懇親会の場でとり行われた。表彰 式に続いて, 高畑会長の開会挨拶, 菅原年次大会実行委員 長の乾杯の発声で懇親会が開始された. その後, 会場のご 提供，ならびに会場世話人を務めていただい三重大学の鶴 岡副学長にご挨拶を頂いた. 若手研究者まで幅広く交流が 行われ親睦が深められた。

\section{3. 講演の概要}

\section{1 一般講演}

第1部門：画像符号化 1

発表 3 件, 参加者 23 名. 参加者がやや少ない点は, 報告 †株式会社 KDDI 総合研究所

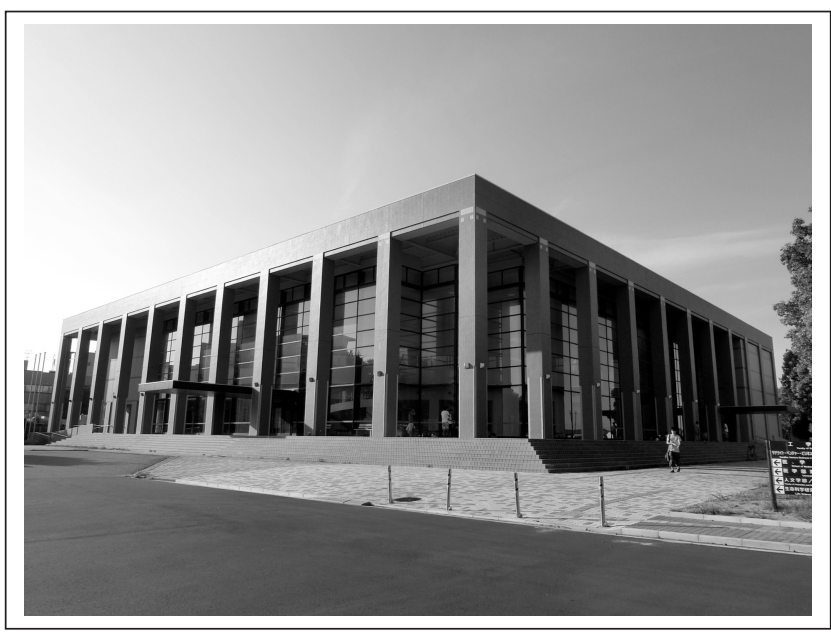

図 1 会場となった三重大学

件数が少ないために他よりも開始時間が遅かったことや， 次のセッションと連続して同じ分野であったためと思われ る. 質疑応答については活発な議論とまではいかなかった が，各講演とも会場からの質問，コメントが寄せられた。

第2部門：VR \& AR

発表 4 件, 参加者 21 名. タブレット端末を用いた ARに 関する発表が 1 件，HMDを用いたVRに関する発表が 3 件 あった. 開催初日の午前の部の割に, 多くの参加者にご参 加いただいた．途中入室される方もみられ，VR/AR分野 に対する関心の高さを感じた．質疑については各発表 1 3 件ほどで，発表者に対して参考となる意見交換ができた ものと思われる。

第3 部門 : 放送方式 1

発表 4 件, 参加者 16 名. 参加者は放送業界の関係者が多 かった。ネット配信, エリア放送, HDR伝送など今の業界 で関心の高いテーマであったこともあり，活発な議論がな された。

第4部門：画像符号化2

発表 4 件, 参加者 24 名. 大学の先生を筆頭に, 活発な議 論が行われた。いくつかの発表では, 座長からの質問のみ であった。

(97) 97 


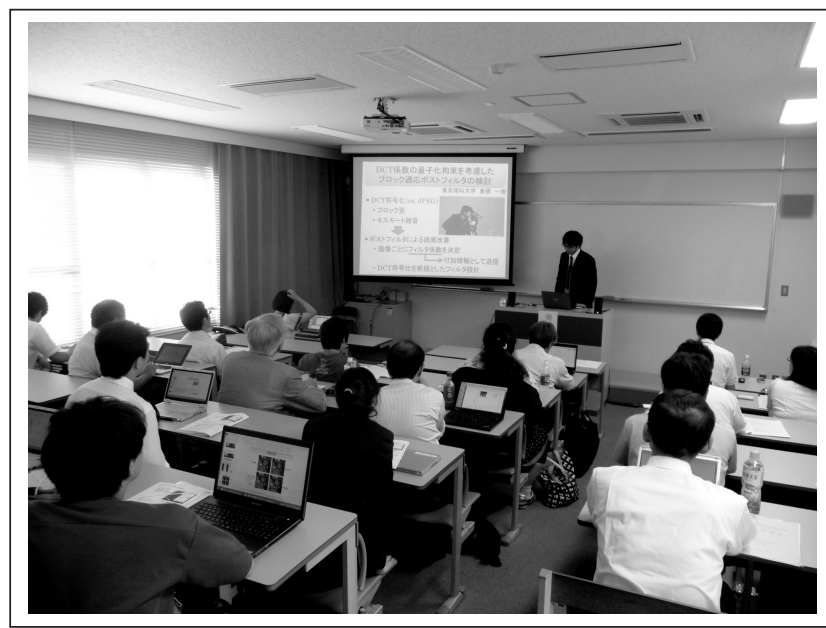

図2 講演風景

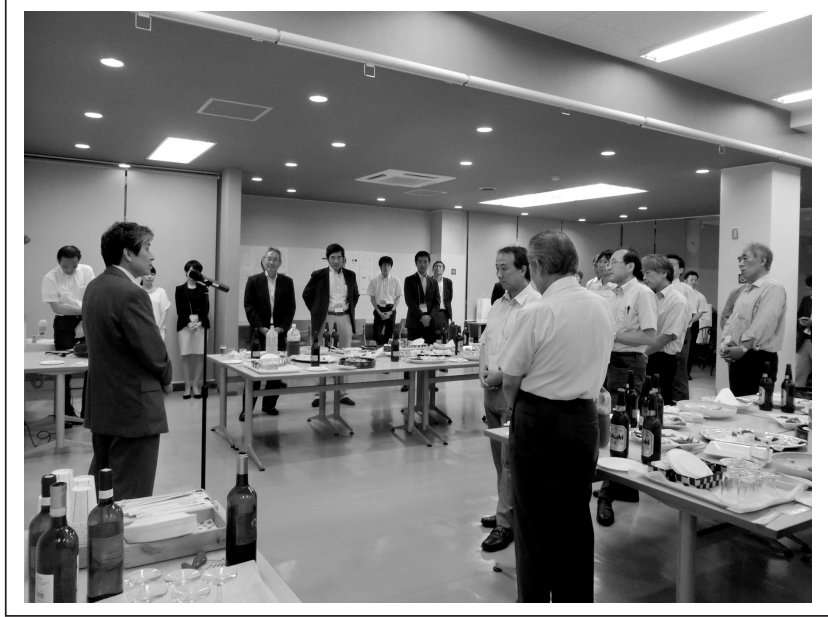

図3 懇親会風景

\section{第5部門：ディスプレイ}

発表 4 件, 参加者 18 名. 参加者は他セッションと比較し て少なめではあったが, 質疑応答では活発な議論が取り交 わされた。 ただ質問内容によってはコンフィデンシャルで 回答されない内容もあった. 学生の聴講も多数みられたこ とから，本業界を担う技術者の育成という点でも本セッ ションの意義は高いと思われる.

\section{第6 部門：放送方式2}

発表 4 件，参加者 17 名. 主に地上デジタル放送に関わる 講演により構成された. 質疑応答では大学の先生を中心に 活発な意見交換が行われた.

\section{第7部門：メディア処理基礎 1}

発表5件, 参加者 23 名. 画像処理の応用に関する研究発 表が多かった。新たな技術の開発というよりも, 実際の画 像処理の課題に対して, 既存の画像処理手法を組合せ, そ の性能評価を行った研究発表が多かった. 5 件の講演とも 会場からの質問があり，セッションの状況は良好だったと 思われる。

第8部門：放送方式3，コンシューマエレクトロニクス 発表 5 件, 参加者 16 名. ハイブリッドキャストに関連す る発表 4 件を含め，すべてが放送と通信を連携させたサー ビスに関連する発表であった。そのうち 3 件が放送と通信 あるいは通信のみで伝送される複数コンテンツの同期に関 する検討, 残りの 2 件がテレビ視聴と実行動を結び付ける システムに関する検討であった，参加者は 20 名弱ではあっ たが，活発な質疑が行われた。

第 9 部門：メディア処理基礎 2

発表 4 件, 参加者 16 名. マンガ画像からのメタデータ抽 出, 自律走行車のためのノイズ除去, 番組映像のシーン分 割, 動画像を対象とした 3 次元 DCT と 3 次元 DFT の比較 に関する 4 件の講演があった. 各講演に対して $3 \sim 5$ 件の質 問があり，活発な議論，意見交換がなされた。

\section{第 10 部門：放送現業1}

発表 4 件, 参加者 15 名. 別会場でのセッションの人気が 高かったのか, 参加者数は 20 名弱とあまり多くはなく, 学 生の数も少なかった。各講演に対して会場から 1 件程度の 質疑があり，時間に余裕のあるケースでは座長より質問・ コメントを提示した。

第11部門：コンピュータビジョン1

発表 4 件, 参加者 35 名. 3 次元物体の画像検索に関する 発表が 1 件, カメラ校正に関する発表が 2 件, 深度マップ 推定による物体の寸法推定に関する発表が1件行われた. 午前 9 時に開始のセッションにも関わらず，冒頭から 20 名 程度の参加者数で, 注目度の高さがうかがえた. 各発表に ついて $2 \sim 3$ 件の質疑応答が交わされた.

\section{第 12 部門 : 放送現業 2}

発表 4 件，参加者 33 名. ハイブリッドキャストや $4 \mathrm{~K} / 8 \mathrm{~K}$ に関わる放送応用技術に関わる講演が行われた。常時，30 名の参加があり，活発な質疑とともにコメントが出される など，貴重な意見交換の場となった.

\section{第13部門：センシング1}

発表 4 件, 参加者 20 名. バイオメディカル用途や車載, 監視カメラなど撮像デバイスのさらなる性能向上が期待さ れている最先端のセンシングデバイスに関する研究報告が 行われた. 参加者は 20 名前後とやや少なめではあったが, 中身の濃い質疑応答が行われた。

\section{第14部門：メディア処理基礎 3}

発表 4 件，参加者 21 名. 30 名ほど収容可能な教室に対し， 常時，20名ほどの参加であった.メディア処理のセッショ ンは発表分野が多岐にわたる影響か，全発表を通して会場 からの質疑は限定的であった。今後のプログラム編成にお いて，セッションの細分化などの配慮が必要といえる.

第15部門：コンピュータビジョン2

発表 4 件, 参加者 27 名. ステレオマッチングの高速化, 認知症の識別, AR向けツール, カメラ映像からの人物追 
跡と, 各講演が属する研究分野は多岐に亘っていた. 参加 者は比較的多かったものの, 会場からの質疑はセッション を通じて 2 件とやや低調であった.

第 16 部門：放送方式 4

発表 4 件, 参加者 19 名. フルスペック $8 \mathrm{~K}$ に対応したカ ラーグレーディング装置, ブランキングスイッチャー, 同 期システムに関する発表があった. いずれも実用化試験放 送に向けた研究であり, SHV 制作環境の向上が期待される. 残りの 1 件はUHDTVカメラのMTF測定に関するもので あった. 本格化するSHV 制作に向けて, 機器の信頼性や実 際の運用に関して幅広い質疑が活発に行われた。

第 17 部門：センシング 2

発表 4 件, 参加者 14 名. スーパーハイビジョンカメラシ ステムと X 線 CT 用センシングデバイスの報告があった. 前者は，単板式ではじめてフルスペックに対応した小型 ポータブルカメラの開発に関するものであった。後者は, 産業医療セキュリティなどの分野で非破壊検査に用いられ ている。 今回，X線検出器に関して 3 件の報告があった. 参加者はやや少なめではあったが中身の濃い質疑応答が行 われた。

第18部門：メディア処理基礎 4

発表 5 件，参加者 18 名. 肌色領域や岩領域などの識別, テニス映像の閲覧手法, 歪み補正, コントラスト改善に関 わる講演が行われた. 非常に活発な質疑, 議論があり, 座 長から質問する機会はほとんどないような状況であった.

第19部門 : コンピュータビジョン3

発表 4 件, 参加者 34 名. 最後のセッションであったため か, 多数の参加があった. 特に, 単眼カメラを用いたド ローンによる自動追跡に関しては，その実用性について活 発な議論が行われた。

\section{第20 部門：深層学習・パターン認識}

発表 5 件，参加者 24 名. 表情検出，手形識別，肌理解析， 鳥検出, 猫の品種識別をそれぞれ扱う画像処理に関する講 演が行われた．多くの講演においてその目的が明確であっ た点が奏功し，質問の数も多く活発な議論ができた.

第21部門：センシング 3

発表 5 件, 参加者 22 名. 近年注目を集めているマルチス ペクトルイメージング, 高速移動体のトラッキング, ディ ジタルホログラフィック像再生, 光線空間取得など, 通常 のビデオ映像よりも飛躍的に高い性能が要求される 5 件の 講演が行われた。参加者はやや少なめではあったが, 中身 の濃い質疑応答が行われた.

\section{第22部門：放送方式5}

発表 5 件, 参加者 31 名. 本セッションではスーパーハイ ビジョンのための次世代地上波放送に向けたNHKの研究 開発に関する 5 件の発表があった。 参加者からは高い関心 が寄せられ, 活発な質疑討論が行われた結果, 各講演に割 り当てられた時間がやや不足気味であった。
第23部門：無線・光伝送 1

発表 4 件，参加者 18 名. 水中光伝送用送信機，ミリ波带 アンプ, ディジタル FM 変調器に関わる講演が行われた. 参加者はそれほど多くないものの, 実験やハードウェアの 詳細について質問があり, 活発な議論が行われた。

第24部門 : 高臨場感システムの心理・生理/認知科学

発表 4 件, 参加者 31 名. 認知症の診断テストや，仮想環 境における協調作業などの研究では, 実験の前提条件を確 認する質問が寄せられた。また，課題に対するアプローチ が適切かを指摘する質問，さらに得られた結果の解釈の妥 当性，他の解釈の可能性などに関する質問が寄せられた. 活発な議論が行われ，発表者らにとっても有意義な議論の 場となったと思われる。

\section{第25部門：スポーツ科学応用}

発表 4 件, 参加者 40 名. 多視点ロボットカメラ, ボール の 3 次元追跡, 練習に効果的な映像の撮影・解析に関わる 研究発表が行われた。最終日の午前のセッションであった が，教室がほほ満室となるほどの盛況ぶりであり，活発な 質疑，議論が行われた。

\section{第26部門：無線・光伝送2}

発表 4 件，参加者 19 名. 64 APSK符号化変調やFPU伝送 設備に関わる講演が行われた。やや少ない聴講人数である が，特に測定結果などに質問が多くあり，熱心な議論がな された。

\section{第27部門：パターン認識・情報デザイン}

発表 4 件，参加者 34 名. サッカー選手の顔向き推定，文 字認識, 静脈抽出, 不可視画像の指標化に関わる研究発表 が行われた。 大半の講演において，聴講者からの質問が多 く活発な議論が行われた。

\section{第28部門：メディア処理応用}

発表5 件, 参加者 16 名. 映像配信制御, TVML の演出手 法・ツール開発, ソーシャルグラフ分析, 学習支援システ ムに関わる研究発表が行われた.いずれの講演に対しても, 会場から多くの質問が寄せられ，活発な議論が行われた.

\section{第29部門：立体映像技術 1}

発表 5 件, 参加者 26 名. 立体視における眼の輻輳運動, な らびに奥行き知覚に関わる講演が行われた。講演関係者以 外もかなり参加されていると考えられる．質疑応答に関し ては，座長が口を出せないほどに，活発な議論がなされた。

第30部門：ヒューマンインタフェース

発表 5 件，参加者 13 名. 静岡大学より，赤外照明を用い た瞳の角膜検出により注視点方向をセンシングする技術に 関する 3 件の発表があった。次いで，名城大学より，市販 のスマートウォッチの入力システムを, 独自の入力方式に 改修して実験した結果について 2 件の発表があった。全体 的に余裕を持って進行でき，定刻どおりに終了できた。

第31部門：CG \&映像表現

発表 5 件, 参加者 23 名. 点群データからの欠損検出, 
RDP法の統計的性質の検証, りんごの糖度推定, 大動脈弁 の開閉シミュレーション, ワイパーによる排水処理のシ ミュレーションに関わる研究発表が行われた. 最終日の最 終セッションということもあり, 講演関係者以外の参加者 が少なく，質疑は座長を中心に行われた。

\section{第32部門：立体映像技術2}

発表 6 件, 参加者 20 名. カメラ軌跡の抽出, アクティブ 照明による 3 次元奥行き計測, TN-LCDにおける輝度の加 減算, 積層多眼 DFD, インテグラル立体表示に関わる研究 発表が行われた．最終日の最後のセッションということも あり, 少し参加者が少ない印象であった. 発表者とその共 著者で多くを占めていた印象ではあるが, その分, 質疑応 答では専門的見地から深い質問が交わされた.

第33 部門 : ストレージ

発表 5 件，参加者 10 名. $8 \mathrm{~K}$ 映像の記録再生に関する実用 的な技術や将来技術がシリーズで発表され，多くの質問が 出された. 最終日の最終セッションであるせいか参加者は やや少ない印象を受けた。

\section{2 公開講演会「放送メディアを活用した観光開発と 地方創生」}

参加者 169 名. 公開講演に先立って, 高畑会長の挨拶, 次いで三重県知事の鈴木英敬氏の挨拶が行われた. 公開講 演は, JR東海特別顧問の松本正之氏を講師として招き, 大 会参加者に限定せず，一般の方も聴講できる形で開催され た，以下に，講演内容について触れる。本が持っている 有効な観光資源を生かし, いろいろな観光産業を活性化さ せることは，これからの日本の発展および地方の創生に欠 かせないものである，その観光開発は，まず放送・映像メ ディアによる五感への訴求, そして「行ってみたい!」とい う動機付けなしには成り立たないといえる.鉄道事業も， 観光客を増加させるため, 移動の速さや利便性を向上させ ているが, 加えて, 映像メデイアとのコラボレーションが 大きな効果をあげている. 本講演では, これら, 観光, 映 像メディア, 鉄道, そして地方創生など, お互いの強い結 び付きについてご報告頂いた。

講師の松本氏はNHKの元会長ということもあり, 放送 事業者の視点から，映像メディアをタッチポイントとした， 観光ビジネスや地方創成のアプローチを非常にわかり易く ご説明頂き, 当学会員のみならず, 学生を含む一般聴講者 にとっても共感できる内容であった。

\section{3 シンポジウム}

S1「ついに始まった世界初の8K衛星試験放送」

発表 4 件, 参加者 36 名. $8 \mathrm{~K}$ 試験放送の概要について導入 が行われた後, 制作設備・中継車, 送出設備, 受信システ ムについて, それぞれ有識者からの講演が行われた. 高度 BSにより $8 \mathrm{~K}$ 試験放送が開始された直後ということもあ り, 多くの参加者の関心を集め, 質疑応答も活発であった. S2「VR技術の進歩が映像サービスにもたらすインパクト」

$100 \quad(100)$

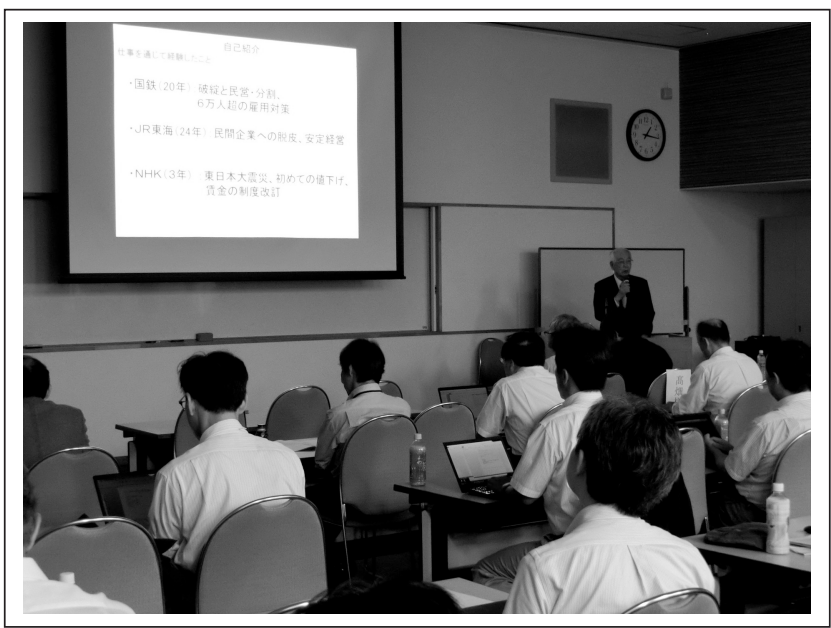

図4 公開講演風景

発表6件, 参加者 52 名. 主に海外の家電技術動向として, 360 度映像や HMD といったVR（バーチャルリアリティ）関 連技術における進展が著しい. 本講演会では, 研究, メー カ, サービス (放送, 通信)にわたるそれぞれの切り口から, 最新の技術トレンド・研究開発動向を紹介し，2020年に向 けたサービスイメージ・利用シーンを踏まえた新規創出市 場の展望を行った。質問する来場者は多少偏り気味であっ たが，活発な質疑が行われた。

S3「ネットワーク時代における映像情報メディアの役割 と今後〜 IoTを中心に〜」

発表 5 件, 参加者 44 名 (午前), 39 名 (午後). 50 人以上 の聴衆が集まり熱心に講演に耳を傾けていた. 時間の関係 で会場から多くの質問を受けることができなかったが，来 るべく時代に技術者がどう対応していけばいいのか, 講演 者にコメントを求める姿が印象的であった。

S4「映像情報を用いた物体追跡技術の最前線とスポーツ 科学への応用動向」

発表 3 件, 参加者 30 名. カメラ映像の解析による人物の 運動解析, スポーツスキルの獲得支援技術, 多視点・超高 精細カメラによる撮影技術など, さまざまな目的での研究 事例について報告があった。会場がほぼ満席になるほどの 盛況で多くの参加者を集めた (およそ 40 名). 発表後の質 疑応答でも，予定していた時間を超過してしまうほどの活 発な意見交換がなされた. セッション終了後も会場で発表 者を取り囲んで議論している様子も見られ，今後の発展に 期待が持てる結果となった.

\section{4 チュートリアル $4 \mathrm{~K} / 8 \mathrm{~K}$ 放送サービスを可能にする ARIB 標準規格と運用基準〜スタジオ編」}

発表 4 件, 参加者 30 名. $4 \mathrm{~K} / 8 \mathrm{~K}$ 放送サービスを実現する ための ARIB 標準規格について，映像，音響，インタ フェースの側面から，それぞれ実際の ARIB標準化活動を 手掛ける有識者による講演が行われた。高度BSでの $8 \mathrm{~K}$ 試 験放送開始に伴い，非常にタイムリーな企画であり，貴重 


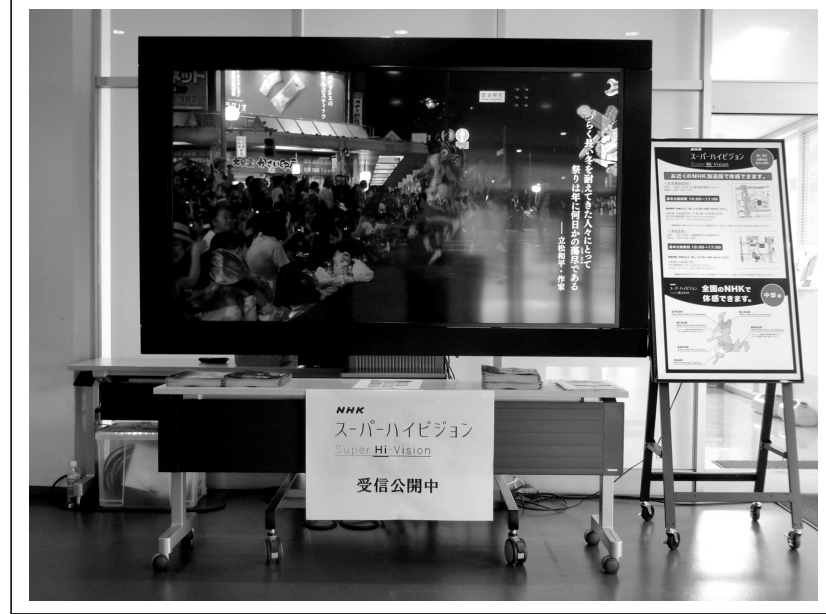

図5 スーパーハイビジョンのデモ展示

な情報提供機会となった。

\subsection{SET ジョイントセッション}

発表 1 件，参加者 15 名.テレビ会議による講演として， GLOBOSATのLourenco Carvano氏より，リオ五輪でのス ポーツ中継について，システムおよびサービスの側面から 説明頂いた.ブラジルSETとの初の試みとして企画した ジョイントセッションであり, 今後の両学会での親交を図 る上で，非常に意義深いイベントとなった。ささに同日の 夜には, サンパウロで開催中のSET Expoでの超高精細テ レビに関わるセッションにおいて, 当学会より $8 \mathrm{~K}$ 放送 サービスに関わる講演を同じくテレビ会議により実施し

た. 講師はNHK浜口氏にご対応頂いた.

\section{$3.6 \mathrm{KIBME}$ 招待講演}

発表 1 件, 参加者 28 名. 韓国で来年 2 月から開始される $4 \mathrm{~K}$ 地上デジタル放送の技術概要を説明. 物理層からプレ ゼンターション層までATSC3.0に準拠した規格となってお り，モバイル向けHDTV放送と固定受信機向けUHDTVの 放送をSHVCを用いた階層符号化により実現している。こ の仕組みを使うと $3 \mathrm{DTV}$ の放送も可能である. 映像デモを 交えてわかりやすく説明があった。

\section{7 デモ展示}

大会期間中， $8 \mathrm{~K}$ 試験放送受信，VR体験，ディジタル情 報スタンドのデモ展示が行われた。 $8 \mathrm{~K}$ 試験放送受信は NHK 放送技術研究所の協力により, $8 \mathrm{~K}$ 映像および 22.2 チャネル音響の視聴体験を可能とした。VR体験および ディジタル情報スタンドは企業による展示であり, それぞ れHTC NIPPON，（株)ミライトにより運営頂いた.

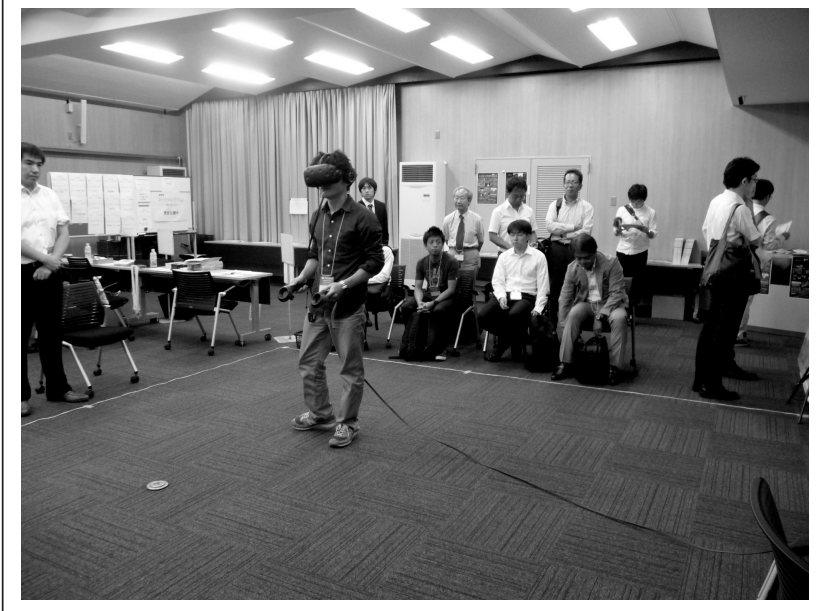

図6 VR体験風景

\section{4. むすび}

今大会では，ブラジル SET との連携によるジョイント セッションの開催, 韓国 KIBMEの招待講演, 企業による デモ展示など新しいことに数多く挑戦し，いずれも多くの 参加者から好評を得られた. 本大会が研究者や会員, それ から今後の映像情報メディアをもり立てていくであろう多 くの学生の交流の場となり, 一層の技術の発展の契機にな れば幸いである。

最後に，本大会を開催するにあたり，ご尽力いただいた すべての関係者に心より感謝を申し上げる．特に会場提供 やさまざまな企画において多大なるご協力を頂いた三重大 学の関係者の方々, 部門運営と進行にご尽力いただいた幹 事，座長，司会者，講演を快くお引き受けいただいた講演 者の方々，そして大会を盛り上げていただいた参加者の皆 様に，厚く御礼申し上げる。次年度の年次大会がさらに大 規模かつ盛況に開催されることを祈念する．なお，本報告 は，各部門の座長，司会者等から提出された資料・報告を 基に，一部を引用して作成したものである.

(2016年11月 2 日受付)

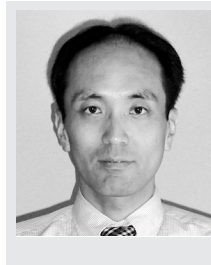

内势藤整 1994 年, 早稲田大学理工学部電子通 信学科卒業. 1996年, 同大学大学院修士課程修了. 同 年, 国際電信電話 (株) (現 KDDI (株)) に入社. 以来, 同社研究所にて, 主にHDTVを始めとする動画像符号 化および伝送方式の研究・開発に従事. 現在, (株) KDDI 総合研究所超臨場感通信グループリーダ. 工学 博士. 正会員. 